\title{
OCCURRENCES OF THE LAND PLANARIAN RHYNCHODEMUS SYLVATICUS IN GREAT SMOKY MOUNTAINS NATIONAL PARK
}

\author{
BENNY GLASGOW \\ Principal investigator GRSM-00341, 101 William Street, Vernon, AL 35592 \\ Corresponding author: wildnature52@yahoo.com \\ PAULA PIERCE \\ 5830 N. Blue Lake Dr., Norman, OK 73069 \\ E-mail: Paula@excaliburpathology.com
}

\begin{abstract}
Six land planarians collected in Great Smoky Mountains National Park from 2006 to 2012 are identified as Rhynchodemus sylvaticus (Leidy, 1851). External and internal characteristics of reported specimens are described using photographs. A discussion of the species' taxonomy, distribution, conservation concerns, and possible means of introduction is given.
\end{abstract}

\section{INTRODUCTION}

Park researchers collected a previously unreported land planarian 28 July 2006 (Discover Life in America, ATBI 2008). The specimen measured $7 \mathrm{~mm}$ long and was tentatively identified as Rhynchodemus sp. based on external characteristics and behavior (Ogren 1991). Searches on 19 June 2012 collected two land planarian specimens. One of these was found to be sexual after sectioning and the histology of the copulatory apparatus examined. Three additional land planarians with similar external characteristics were found 21 June 2012. All six specimens were a gray or brown color with two longitudinal stripes and most had darker brown anteriors, which are external characteristics given for Rhynchodemus sylvaticus (Ogren 1989).

External characteristics vary in $R$. sylvaticus and individual specimens may superficially resemble other species. Also, it is possible a new species may have external features that are similar to $R$. sylvaticus. Examining specimens for external and internal features, especially features of the reproductive anatomy, of wellfixed and stained sections is needed to identify the species with certainty. A description of internal anatomy of specimens collected from Great Smoky Mountains National Park may contribute to improved identification of $R$. sylvaticus.

\section{METHODS AND MATERIALS}

Specimens were fixed in Excalibur's Alcoholic Z-Fix, then processed to paraffin. Some specimens were taken alive for examination and photographed before fixation. Four specimens were serially sectioned at $5 \mathrm{M}$ and stained with Hematoxylin with Eosin counter stain, and mounted on slides. Prepared slides were examined using a compound light microscope.
Materials used are archived in the Great Smoky Mountains National Park collections, Gatlinburg, TN. These include notes, digital photographs, and four sets of specimen slides: BG2012-09A, BG2012-011A, BG2012011B, and BG2012-011C. All specimens are in longitudinal sections except for BG2012-011C, which is longitudinal and cross-sectioned. Photographs and notes of two additional specimens are included in Park records.

\section{RESULTS}

Five specimens had body pigmentation in shades of light gray, dark gray, chocolate, and brown with darker anterior and posterior ends (Fig. 1). One smaller specimen lacked darker anterior pigmentation (Fig. 2) and was an overall gray shade without magnification. Specimens were observed lifting the anterior end, at times at a perpendicular angle to the rest of the body, and making a waving motion with the lifted part. Forward lunging motions were seen as the animals crawled. Two dorsal longitudinal stripes were present in all specimens, but difficult to see without magnification. Specimens had a single pair of eyes on the anterior portion of the body (Figs. 1-3). One specimen had more distinct stripes and had eyespots situated at a considerable distance from the anterior end (Fig. 2). All specimens had external characteristics and behaviors consistent with those described for $R$. sylvaticus (Ogren 1989).

Cross sections revealed bundles of longitudinal muscles indicative of subfamily Rhynchodeminae (Fig. 4). Individual longitudinal muscle fibers were visible in the bundles at greater magnifications. Eyes were visible in sections of specimens (Fig. 3). Longitudinal sections of an asexual specimen showed the early development of the copulatory apparatus. Sections of a sexual specimen 


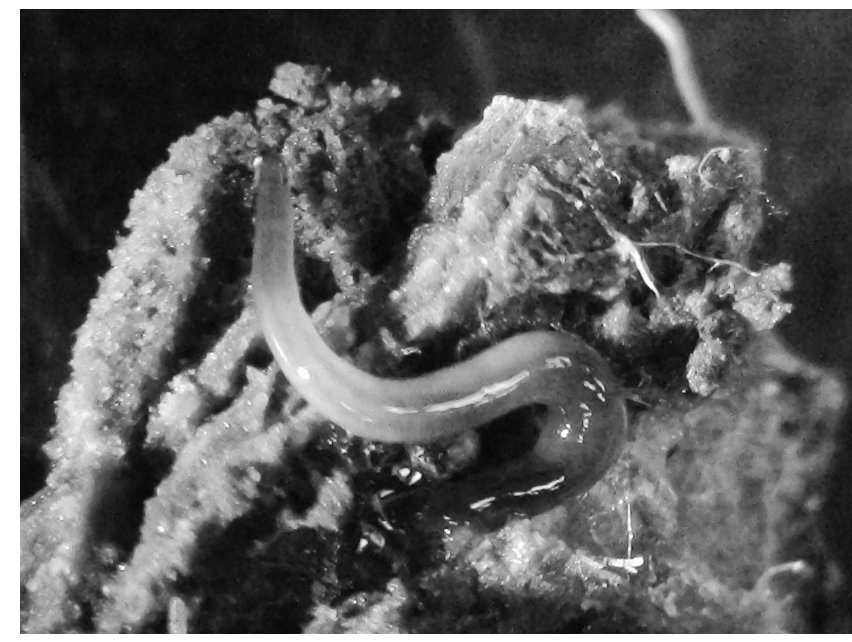

FIG. 1. Land planarian specimen from Great Smoky Mountains National Park showing light and dark shading, eyes, and light longitudinal stripes. Anterior is at the top of picture.

revealed the male copulatory apparatus clearly visible and its border easily defined and set off from surrounding tissue being oval in shape, or ovoid-shaped viewed three dimensionally (Figs. 5-7). The female apparatus was also followed and appears about half the length of the male apparatus. The end of the female tract near the gonopore

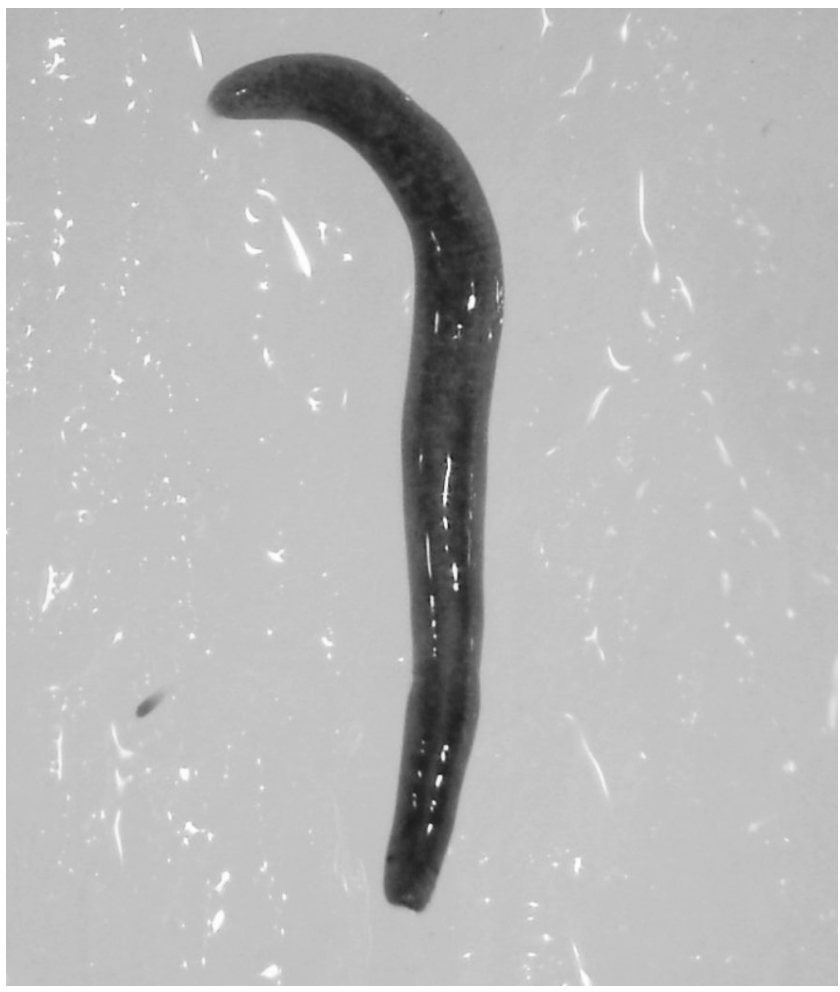

FIG. 2. Specimen collected in the Great Smoky Mountains National Park 28 July 2006 showing longitudinal stripes, anterior eyes, and body shading. Anterior is at the bottom in picture. Collected by Park researcher Dan Dourson.

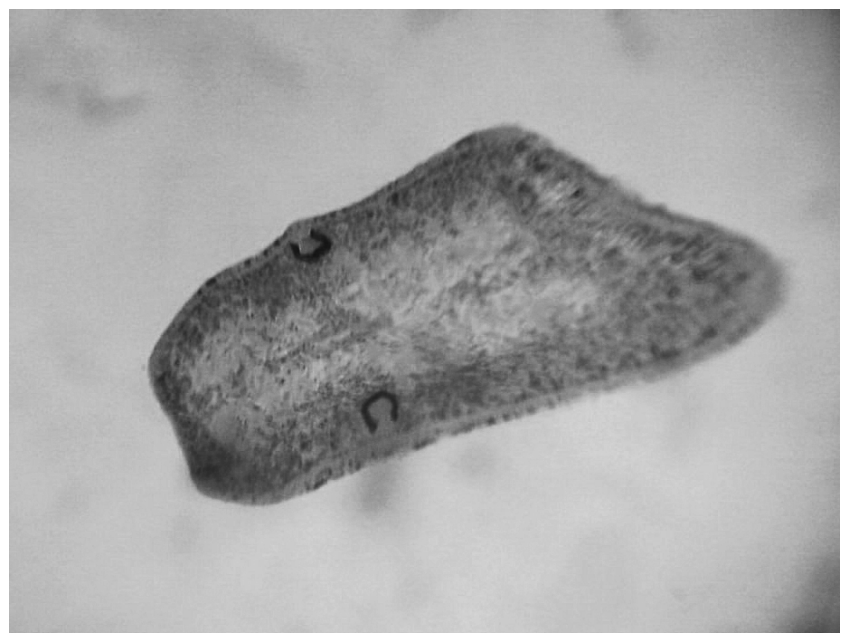

FIG. 3. Longitudinal section of the anterior part of a land planarian specimen collected 21 June 2012, showing part of the pigment cups of the single pair of eyes.

is expanded (Fig. 6). The sexual specimen collected in the Park was within the range of internal sexual anatomy described for R. sylvaticus (Figs. 5-7).

\section{DESCRIPTION OF COPULATORY APPARATUS IN SEXUAL SPECIMEN}

The gonopore in the preserved specimen is about $0.75 \mathrm{~mm}$ posterior of the mouth (Fig. 5). The gonopore leads to the general genital antrum, where there are separate openings to the male and female reproductive antrums. The male copulatory apparatus, situated anterior to the gonopore, is clearly differentiated from the general body parenchyma (Hyman 1943) and is a long ovoid shape about $0.5 \mathrm{~mm}$ in length. The male

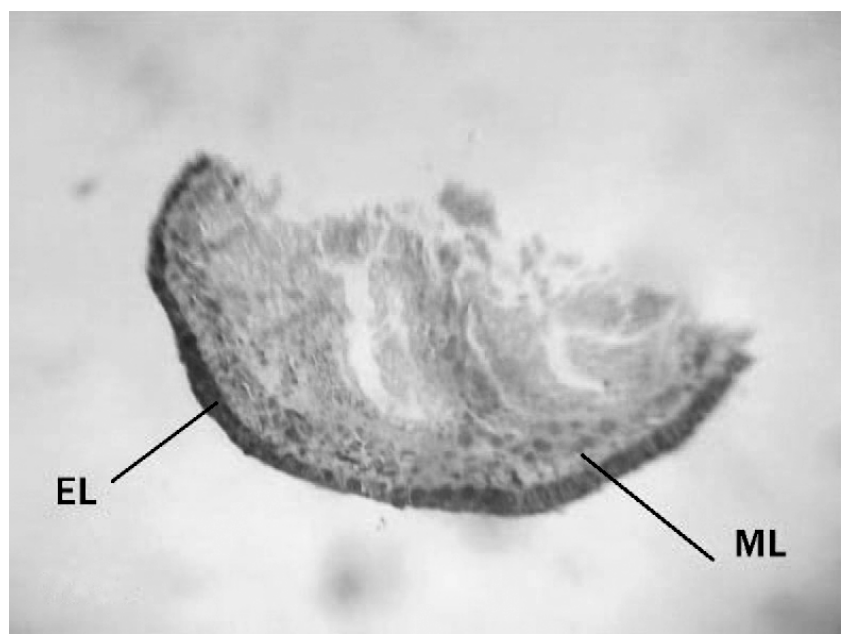

FIG. 4. A cross section of a specimen collected 21 June 2012 showing bundles of longitudinal muscle tissue (ML). These appear as a layer of small circles under the epidermis layer (EL). Specimen collected by Benny Glasgow. 


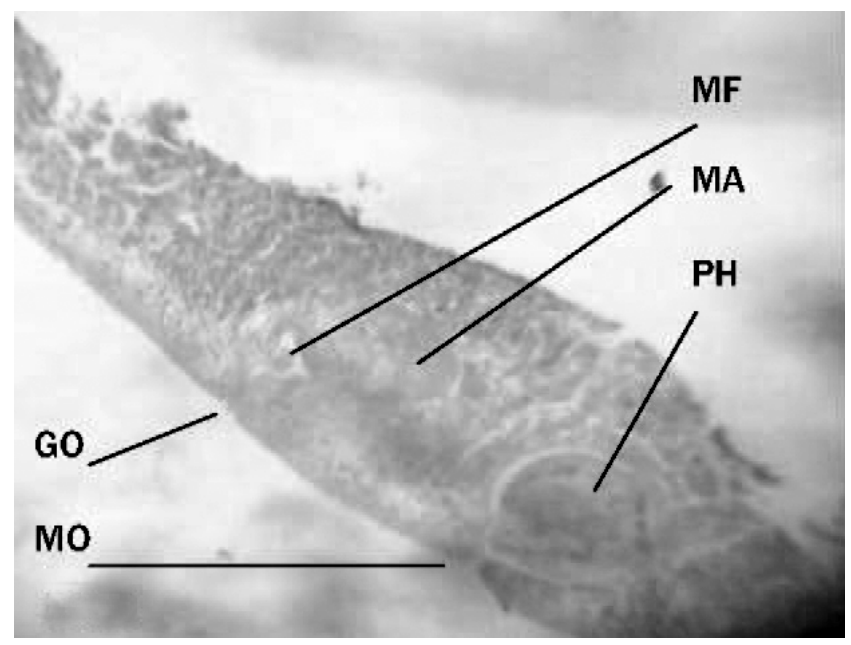

FIG. 5. Longitudinal section of a specimen of $R$. sylvaticus collected in the Great Smoky Mountains National Park 19 June 2012 showing gonopore (GO), mouth (MO), pharynx (PH), male apparatus (MA), and fold of tissue at opening of male antrum (MF). Ventral part is toward the bottom, dorsal part is at the top, and posterior is to the left. Specimen collected by Rachel Grabenstein.

antrum is a wide cavity with folded walls and has a thick internal lining formed by an epidermis having numerous long extensions and with a thin muscle layer underneath. A protruding fold is seen at the opening of the male antrum (Fig. 5) as is described for R. sylvaticus (Ogren 1989; Kawakatsu et al. 2003). Two sperm ducts staining cyanophilic are seen in the sections and these unite at the anterior part of the male copulatory apparatus (Fig. 7). The female antrum is about $0.25 \mathrm{~mm}$ long with a wide expansion at its opening and narrows at the posterior end. However, there is

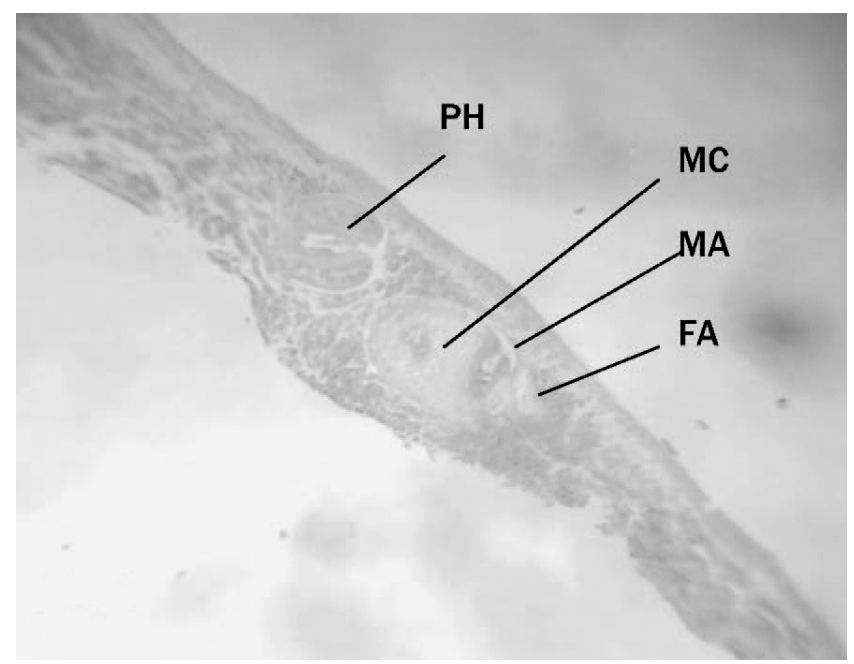

FIG. 6. Longitudinal section of a specimen of $R$. sylvaticus collected 19 June 2012 showing pharynx (PH), oval shaped male copulatory apparatus (MC), beginning of male antrum (MA), and expanded portion at the beginning of female antrum (FA). Ventral part is to the top and posterior is to the right in picture.

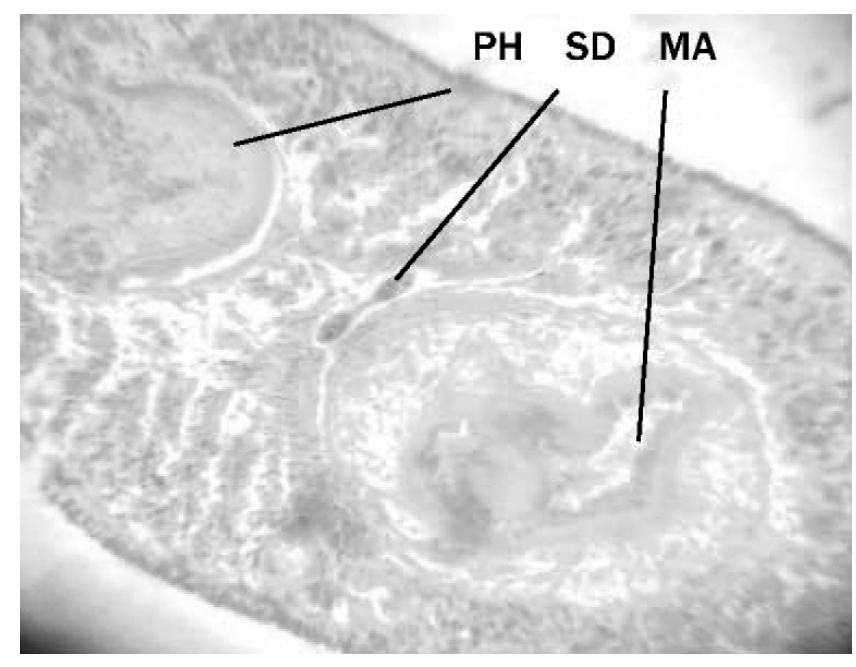

FIG. 7. Longitudinal section of a specimen of $R$. sylvaticus collected 19 June 2012 showing pharynx (PH), sperm ducts (SD), and male antrum (MA). Ventral part is at the top and anterior is on the left in picture.

contraction from fixation of the specimen and the female antrum length may be longer in the living animal. The female antrum is lined with a thick epidermis (Fig. 5) and has eosinophilic staining surrounding its course. Two oviducts are seen at the posterior part of the female antrum. The oviducts are lined with thick epidermis and have narrow openings. The two oviducts join to the posterior portion of the female antrum. The female copulatory apparatus is about one-half the size of the larger male copulatory apparatus. The copulatory apparatus of the mature Park specimen is as described for R. sylvaticus (Hyman 1943; Ogren 1957).

\section{TAXONOMY}

The following classification scheme is that of Sluys, Kawakatsu, Riutort, and Baguñà (Sluys et al. 2009):

Order: Tricladida, (Lang 1884)

Suborder: Continenticola, (Carranza et al. 1998)

Superfamily: Geoplaniodea (Stimpson 1857)

Family: Geoplanidae (Stimpson 1857)

Subfamily: Rhynchodeminae (Von Graff 1896)

Genus: Rhynchodemus (Leidy 1851)

Species: $R$. sylvaticus (Leidy 1851)

\section{DISCUSSION}

The variation of characters used in identifying Rhynchodemus sylvaticus has led to a number of synonyms for the species. $R$. sylvaticus was first described by Leidy (1851) from Pennsylvania. Material from the description are reported lost (Walton 1915). $R$. bilineatus (Mecznikov 1865), described from Europe, is synonymized with $R$. sylvaticus (Ball and Reynoldson 
1981; Minelli 1977; Ogren 1986a; Ogren 1989). $R$. americanus (Hyman 1954) is synonymized with $R$. sylvaticus (Ogren 1989). Minelli (1977) lists several other species synonymized with $R$. sylvaticus. The web site http://turbellaria.umaine.edu (Tyler et al. 2006-2012) lists several other synonyms.

External characters vary for $R$. sylvaticus (Ogren 1957). Body coloration may appear lighter to darker shades of gray, brown, chocolate brown, to almost black. A reddish tint is also reported (Ogren 1989). Two dorsal parallel longitudinal stripes are visible in specimens. However, the stripes are not always easily seen, especially in darkly colored individuals (Ogren 1989). Older specimens may have the dorsal bands disappearing and show a mottled appearance (Ogren 1957). Individuals usually have a single pair of eyes on the anterior end; however, two pairs have been reported in one individual specimen (Walton 1915). Eyes are more difficult to see when individuals are of darker coloration. Placement of eyes is also varied. Specimens of Rhynchodemus with eyes situated farther back from the anterior end have been reported (Hyman 1954).

The six GSMNP specimens examined are consistent with external and internal characteristics diagnostic of Rhynchodemus sylvaticus. Specimens had a pair of longitudinal stripes, a single pair of eyes, and most had darker brown or black anterior and posterior ends. A sexual specimen also had a copulatory apparatus as described for $R$. sylvaticus with a long oval shaped male copulatory apparatus having a wide folded male antrum without a defined penis papilla. The female apparatus also had a long antrum surrounded by a glandular region along its course and also an expanded region connecting to oviducts posteriorly, and without any noted bursa or genito-intestinal connection (Kawakatsu et al. 2003).

The sexual Great Smoky Mountains National Park specimen appears to represent the fully mature condition of $R$. sylvaticus. The descriptions provided by Hyman (1943 and 1954) stated the male copulatory apparatus consisted of antrum only. However, Ogren (1957) mentions specimens in which the wall of the sperm duct protruded into the antrum in the form of a penis papilla. Ogren studied $R$. sylvaticus in captivity and reported that the male antrum is most fully developed in mature specimens that have laid cocoons (Ogren 1957). The expansion seen in the female antrum of the Park specimen may have been from recent laying of a cocoon.

\section{CONSERVATION}

There may be conservation concerns with some introduced species to the Park. It is important to discuss the distribution of $R$. sylvaticus. Initially thought to be endemic to North America, the species is currently considered introduced, although the geographic origin of the species is unclear. Ogren (1991) suggested the species originated from South America and was introduced with imported plants. Similar two-lined and possibly synonymous species are known from the Azores, the island of St. Helena, Brazil, and Equador (Ogren 1991). Graff (1899) also suggested a South American origin. Another suggestion is that the species is originally from Europe and Britain. This suggestion may be based on the finding of specimens in natural wooded areas. Park specimens were also found in natural wooded areas and one relatively remote location. Other reports of $R$. sylvaticus in Europe are from greenhouses (Ogren 1991) indicating a connection to the commercial plant trade. There are no specific studies known addressing the species' origin and information available is insufficient to make any conclusions about the original distribution of $R$. sylvaticus.

Many Park areas were surveyed in search of land planarians and this species has only been found at two locations and is not found widely distributed in the Park. It is difficult to make assertions about a species where only a few specimens are found and then only under certain conditions. Land planarians have a habit of avoiding well-lit areas and taking cover in darker places. Having soft, flexible bodies, they can squeeze into small spaces in soil or in bits of decayed wood (Ogren 1957). The species appears to be adapted to natural areas of the Park. No major harmful effects are reported for this species.

There are a number of ways the species could have been introduced to remote natural areas of the Great Smoky Mountains National Park. The introductions may have occurred before the areas became part of the Park when early settlers to the area planted ornamental plants near their homes. Lloyd (pers. comm.) mentions early residents planted rose bushes and fruit trees and that a lilac bush was planted near a site where the Park specimens were found. Camping and the transportation of firewood to Park areas may be another means of introduction. There is a campsite and campfires near the area where some specimens were found. There was also a Girl Scout campsite near the area in earlier days of Park history (Lloyd 2009). Land planarians and their cocoons could also be transported in soil (Ogren 1957).

Acknowledgments: We thank the staff of the Great Smoky Mountains National Park and Park partners for their assistance. Thanks especially to Discover Life in America staff and volunteers for providing grants, along with volunteers and student interns to assist with the scientific research. Thanks to Rachel Grabenstein, Sarah Pritchett, William Morton, Gerry Middleton, and Carole Middleton, for providing special assistance in collections. Thanks to Hugh Jones for his helpful 
comments. Thanks to Judy Dourson and Dan Dourson for providing some photographs. Thanks also to Great Smoky Mountains Institute at Tremont for providing use of their laboratory and other facilities. Thanks to Todd Witcher of Discover Life in America for assisting with scheduling.

\section{LITERATURE CITED}

BALL, I. R., AND T. B. REYNOLDSON. 1981. British Planarians. Synopsis of the British Fauna No. 19. Cambridge Univ. Press, London. $141 \mathrm{p}$.

DISCOVER LIFE IN AMERICA-ALL TAXA BIODIVERSITY INVENTORY. 2008. The ATBI Database. http://tremont22. campus.utk.edu/ATBI_start.cfm.

GRAFF, L. VON. 1899. Monographie der Turbellarien. II. Tricladida, Terricola (Landplanarien). Wilhelm Engelmann, Leipzig. 575 p.

HYMAN, L. H. 1943. Endemic and exotic land planarians in the United States with a discussion of necessary changes of names in the Rhynchodemidae. Amer. Mus. Novitates 1241(1-21).

HYMAN, L. H. 1954. Some land planarians of the United States and Europe, with remarks on nomenclature. Amer. Mus. Novitates 1667(1-21).

KAWAKATSU, M., E. M. FROEHLICH, H. D. JONES, R. E. OGREN, AND GEN-YUSASAKI. 2003. Miscellaneous papers on turbellarians. Bull. Fuji Women's Univ. No. 41, Ser. II, 89-114.
LLOYD, J. 2009. A Home in Walker Valley: The Story of Tremont. Great Smoky Mountains Assn., Gatlinburg, TN. 51 p.

METSCHNIKOFF, E. 1865. Uber Geodesmus bilineatus Nob. (Fasciola terrestris O. Fr. Muller?), eine europaische Landplanarie. Mélanges biologiques 5:544-565, tab 1.

MINELLI, A. 1977. A taxonomic review of the terrestrial planarians of Europe. Boll. Zool. 44(4):399-419.

OGREN, R. E. 1957. Developmental Observations, the Egg Capsule and Sexual Maturity of the Land Planarian Rhynchodemus sylvaticus. Trans. Amer. Microsc. Soc. 76:43-42.

OGREN, R. E. 1986a. Identity of land planarians with trans-Atlantic distribution: evidences showing that the European Rhynchodemus bilineatus is conspecific with $R$. sylvaticus from Eastern United States. (Abstr.) Proc. Pa. Acad. Sci. 60:90.

OGREN, R. E. 1989. Identification features of the Two-lined land planarian Rhynchodemus sylvaticus, with evidence that Rhynchodemus americanus is conspecific. Trans. Amer. Microsc. Soc. 108(1):40-44.

OGREN, R. E. 1991. Land Planarians from Ontario and Quebec, Canada. Trans. Amer. Microsc. Soc. 110(1):27-36.

SLUYS, R., M. KAWAKATSU, M. RIUTORT, AND J. BAGUÑÀ. 2009. A new higher classification of planarian flatworms (Platyhelminthes, Tricladida). J. Nat. Hist., 43:29, 1763-1777.

TYLER, S., S. SCHILLING, M. HOOGE, AND L. F. BUSH (comp.). 2006-2012. Turbellarian taxonomic database. Version 1.7 http://turbellaria.umaine.edu.

WALTON, J. B. 1915. A land planarian with an abnormal number of eyes. Ohio Nat. 15(6):498-499. 